<Back to results | 1 of 1

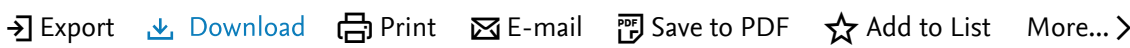

Full Text |View at Publisher|

Document type
Article
Source type
Journal
ISSN
11308621
DOI
$10.1016 / j$.enfcli.2020.12.040

View more $\checkmark$

Enfermeria Clinica • Volume 31, Pages S366 - S371 • April 2021

\section{Healthcare professionals' experiences of delivering sexual and reproductive health services to adolescents: A literature review}

Hamid S.H.A. ${ }^{a}$, , Fallon D. $^{b}, \quad$ Callery P. ${ }^{b}$

国 Save all to author list

${ }^{a}$ Kulliyyah of Nursing, International Islamic University Malaysia, Kuantan Campus, Kuantan, 25200, Pahang, Malaysia

${ }^{b}$ Division of Nursing, Midwifery and Social Work, The University of Manchester, M13 9PL, United Kingdom

$$
\begin{array}{l|l}
8 & \text { View all metrics > } \\
\text { Views count ?? } &
\end{array}
$$

\section{Abstract}

Author keywords

Indexed keywords

SciVal Topics

Metrics

\section{Abstract}

This literature review was conducted systematically to identify the gap in knowledge and practice related to the provision of sexual health to adolescents worldwide. The search was limited to peerreviewed articles published between 2002 and 2018. Thirty-two relevant articles were identified and reviewed for quality assessment by using the Hawker critical appraisal tool. The studies were conducted in Africa, Europe, Asia, Oceania, and the United States of America (USA). The review findings suggested that potential tensions exist between the desire to prevent unwanted pregnancies and the provision of adolescent-friendly sexual health services in societies which disapprove of adolescents ' premarital sexual activity, contraception use and abortion services. Healthcare professionals should be aware of comprehensive sexual and reproductive health services as their
Cited by 0 documents

Inform me when this document is cited in Scopus:

Set citation alert >

Related documents

Views of service providers and adolescents on use of sexual and reproductive health services by adolescents: A systematic review

Onukwugha, F.I. , Hayter, M. , Magadi, M.A.

(2019) African Journal of Reproductive Health

Training in youth-friendly service provision improves nurses' competency level in the Great Lakes Region

Weiss, C. , Elouard, Y., Gerold, J. (2018) International Journal of Public Health

Nurses' perceptions of adolescents accessing and utilizing sexual and reproductive healthcare services in Cape Town, South Africa: A qualitative study Jonas, K. , Roman, N. , Reddy, P. (2019) International Journal of Nursing Studies

View all related documents based on references

Find more related documents in Scopus based on:

Authors > Keywords > 
professional responsibility and the need to manage their own conflicts with regard to fulfilling their role. () 2021 Elsevier Españ a, S.L.U.

Author keywords

Healthcare professionals; Sexual health; Unmarried adolescents

Indexed keywords

SciVal Topics (i)

Metrics

References (20)

View in search results format >

All

Export 合Print 局E-mail 啧 Save to PDF Create bibliography

1 Hawker, S., Payne, S., Kerr, C., Hardey, M., Powell, J.

Appraising the evidence: Reviewing disparate data systematically

(2002) Qualitative Health Research, 12 (9), pp. 1284-1299. Cited 532 times. doi: $10.1177 / 1049732302238251$

View at Publisher

2 Farrag, S., Hayter, M.

A Qualitative Study of Egyptian School Nurses' Attitudes and Experiences Toward Sex and Relationship Education

(2014) Journal of School Nursing, 30 (1), pp. 49-56. Cited 6 times. doi: $10.1177 / 1059840513506941$

View at Publisher

3 Khalaf, Z.F., Low, W.Y., Merghati-Khoei, E., Ghorbani, B.

Sexuality education in Malaysia: Perceived issues and barriers by professionals

(2014) Asia-Pacific Journal of Public Health, 26 (4), pp. 358-366. Cited 13

times.

http://aph.sagepub.com/

doi: $10.1177 / 1010539513517258$

View at Publisher

4 Aksu, H., Kucuk, M., Karaoz, B., Oǧurlu, N.

Knowledge and attitudes of health care providers working in primary health care units concerning emergency

contraception

(2010) Gynecologic and Obstetric Investigation, 70 (3), pp. 179-185. Cited 11 times.

doi: $10.1159 / 000316267$

View at Publisher

5 Sevil, U., Yanikkerem, E., Hatipoglu, S.

A survey of knowledge, attitudes and practices relating to emergency contraception among health workers in Manisa, Turkey

(2006) Midwifery, 22 (1), pp. 66-77. Cited 16 times.

doi: 10.1016/j.midw.2005.03.004

View at Publisher 
6 Warenius, L.U., Faxelid, E.A., Chishimba, P.N., Musandu, J.O., Ong'any, A.A., Nissen, E.B.-M.

Nurse-Midwives' Attitudes towards Adolescent Sexual and Reproductive Health Needs in Kenya and Zambia

(2006) Reproductive Health Matters, 14 (27), pp. 119-128. Cited 78 times. doi: 10.1016/S0968-8080(06)27242-2

View at Publisher

7 Mngadi, P.T., Faxelid, E., Zwane, I.T., Höjer, B., Ransjo-Arvidson, A.-B. Health providers' perceptions of adolescent sexual and reproductive health care in Swaziland

(2008) International Nursing Review, 55 (2), pp. 148-155. Cited 30 times. doi: $10.1111 / j .1466-7657.2007 .00625 . x$

View at Publisher

8 Nalwadda, G., Mirembe, F., Tumwesigye, N.M., Byamugisha, J., Faxelid, E. Constraints and prospects for contraceptive service provision to young people in Uganda: Providers' perspectives (Open Access)

(2011) BMC Health Services Research, 11, art. no. 220. Cited 61 times. doi: 10.1186/1472-6963-11-220

View at Publisher

9 Tilahun, M., Mengistie, B., Egata, G., Reda, A.A.

Health workers' attitudes toward sexual and reproductive health services for unmarried adolescents in Ethiopia (Open Access)

(2012) Reproductive Health, 9 (1), art. no. 19. Cited 54 times. doi: 10.1186/1742-4755-9-19

View at Publisher

10 Alli, F., Maharaj, P., Vawda, M.Y.

Interpersonal relations between health care workers and young clients: Barriers to accessing sexual and reproductive health care

(2013) Journal of Community Health, 38 (1), pp. 150-155. Cited 50 times. doi: 10.1007/s10900-012-9595-3

View at Publisher

11 Godia, P.M., Olenja, J.M., Lavussa, J.A., Quinney, D., Hofman, J..., Van Den Broek, N.

Sexual reproductive health service provision to young people in Kenya; Health service providers' experiences (Open Access)

(2013) BMC Health Services Research, 13 (1), art. no. 476. Cited 38 times. doi: 10.1186/1472-6963-13-476

View at Publisher

12 Kumi-Kyereme, A., Awusabo-Asare, K., Darteh, E.K.

Attitudes of gatekeepers towards adolescent sexual and reproductive health in Ghana

(2014) African journal of reproductive health, 18 (3), pp. 142-153. Cited 15

times.

View at Publisher 
13 Godia, P.M., Olenja, J.M., Hofman, J.J., Van Den Broek, N.

Young people's perception of sexual and reproductive health services in Kenya (Open Access)

(2014) BMC Health Services Research, 14 (1), art. no. 172. Cited 39 times. doi: 10.1186/1472-6963-14-172

View at Publisher

14 Mason, L.

'They haven't a clue!' A qualitative study of staff perceptions of 11-14 year-old female clinic attenders (Open Access)

(2005) Primary Health Care Research and Development, 6 (3), pp. 199-

207. Cited 7 times.

doi: $10.1191 / 1463423605 p c 242 o a$

View at Publisher

15 Tu, X., Cui, N., Gao, E.

Attitudes of family planning workers on the provision of sexual and reproductive health services to unmarried young adults in China (2002) Paper presented at: IUSSP Conference on Southeast Asia's Population in a Changing Asian Context, June 10-13; Bangkok. Cited 2 times.

16 Arousell, J., Carlbom, A.

Culture and religious beliefs in relation to reproductive health (Open Access)

(2016) Best Practice and Research: Clinical Obstetrics and Gynaecology, 32, pp. 77-87. Cited 36 times.

http://www.elsevier.com/inca/publications/store/6/2/3/0/0/4/index.htt

doi: 10.1016/j.bpobgyn.2015.08.011

View at Publisher

17 Thompson, K., Casson, K., Fleming, P., Dobbs, F., Parahoo, K., Armstrong, J. Sexual health promotion in primary care - activities and views of general practitioners and practice nurses (Open Access)

(2008) Primary Health Care Research and Development, 9 (4), pp. 319-

330. Cited 10 times.

doi: $10.1017 / S 1463423608000881$

View at Publisher

18 Breheny, M., Stephens, C.

Irreconcilable differences: Health professionals' constructions of adolescence and motherhood

(2007) Social Science and Medicine, 64 (1), pp. 112-124. Cited 51 times. doi: 10.1016/j.socscimed.2006.08.026

View at Publisher

19 Olivari, M.G., Cucci, G., Confalonieri, E.

"Beyond personal beliefs": Italian health care providers' selfperception of their own job attitudes and reflections on the contraceptive behaviors of adolescent patients (Open Access)

(2016) SAGE Open, 6 (4). Cited 4 times.

https://in.sagepub.com/en-in/sas/journal/sage-open

doi: $10.1177 / 2158244016672714$

View at Publisher 
20 Jaruseviciene, L., Lazarus, J.V., Zaborskis, A.

Confidentiality and parental involvement in adolescent sexual and reproductive health care: A cross-sectional study of Lithuanian general practitioners

(2011) Scandinavian Journal of Public Health, 39 (5), pp. 484-491. Cited 13 times.

doi: $10.1177 / 1403494810396554$

View at Publisher

$\frown$ Hamid, S.H.A.; Kulliyyah of Nursing, International Islamic University Malaysia, Kuantan Campus, Kuantan, Pahang, Malaysia; email:shazariah@iium.edu.my

(C) Copyright 2021 Elsevier B.V., All rights reserved.

$\begin{array}{lll}\text { About Scopus } & \text { Language } & \text { Customer Service } \\ \text { What is Scopus } & \text { 日本語に切り替える } & \text { Help } \\ \text { Content coverage } & \text { 切换到简体中文 } & \text { Contact us } \\ \text { Scopus blog } & \text { 切換到繁體中文 } & \\ \text { Scopus API } & \text { Русский язык } & \\ \text { Privacy matters } & \text { Ууск } & \end{array}$

\section{ELSEVIER}

Terms and conditions $\pi \quad$ Privacy policy $\pi$

Copyright $\left(\right.$ Elsevier B.V л. All rights reserved. Scopus ${ }^{\circledR}$ is a registered trademark of Elsevier B.V.

We use cookies to help provide and enhance our service and tailor content. By continuing, you agree to the 